\title{
ИВАН ЕСАУЛОВ, ПОСТСОВЕТСКИЕ МИФОЛОГИИ: СТРУКТУРЫ ПОВСЕДНЕВНОСТИ, МОСКВА: ИЗДАТЕЛЬСТВО «АКАДЕМИКА» 2015, 616 С.
}

Рецензируемая книга посвящена анализу победного, как диагностирует и представляет автор, влияния мифологических, особенно советских, содержаний и способов мышления на структуры повседневности, определяющие характер сознания, позиций и жизни большинства жителей постсоветской России. Книга состоит из Предисловия, двух основных частей, содержащих в общей сложности около 100 текстов Ивана Есаулова, а также комментарии читателей и ответы на них автора, опубликованные с начала 2012 г. на портале http://esaulov.net, и Послесловия.

В первой из основных частей - Мифологии повседневности: форматирование постсоветского дискурса - предметом анализа стало, если использовать помещенную в книге заметку от автора и издательства, форматирование постсоветского дискурса, которое «рассматривается сквозь призму различных „относительных” мифологий, агрессивно претендующих, однако, на универсальность». Во второй же части - Аксиология русской кульmуры: статьи, интервью, полемика - «представлены как противостоящая этим мифологиям аксиология многовековой русской культуры, так и современные тенденции ее размывания и трансформации». Книга заканчивается весьма необычно оформленным Послесловием - оно состоит исключительно из фрагментов нескольких десятков высказываний русских исследователей и журналистов о более ранних публикациях Есаулова. Воздерживаясь там от какого-либо их комментирования, автор, однако, отмечает ранее в Предисловии, что размещение этих высказываний «будет неплохой иллюстрацией функционирования тех же [мифологических, советских - М. Б.] структур, как и позиций тех, кто пытался [...] преодолеть их тотальное доминирование в нынешнем ,малом времени”» (с. 12).

Приглашая потенциальных читателей к внимательному прочтению книги, я сосредоточусь на основной исследовательской цели-замысле автора и проблемах, связанных с ее реализацией, предваряя это указанием места рассматриваемой книги в его творчестве. Предлагаемый рецензентский подход будет соответствовать исследовательскому самосознанию самого автора, который, заканчивая Предисловие, как раз подчеркнул постоянство и последовательность своей интеллектуальной и общественной позиции: «Все эти десятилетия я пытался идти тем путем, что и предлагаю своим читателям: от РФии к России» (с. 12), ранее уже уточнив, что речь идет здесь о пути, ведущем «от РФии (РСФСР, СССР) к подлинной России» (с. 8). 
Иван Есаулов является профессором Литературного института им. М. Горького на кафедре русской классической литературы и славистики, а также редактором трех Интернет-порталов: «Постсимволизм», «Трансформации русской классики» и «Русская литература: оригинальные исследования». Он опубликовал 10 монографий, среди которых важным интеллектуальным контекстом во время чтения рецензируемой книги являются прежде всего: Категория соборности в русской литературе (1995, 1997), Мистика в русской литературе советского периода (2002), Пасхальность в русской словесности (2004) и Русская классика: новое понимание (2012). В первой из них И. Есаулов представил центральное значение категории «соборности» в способе восприятия, понимания и объяснения мира, веками, как он доказывает, артикулируемого в русской словесности и - шире - ментальности и культуре, выросшей и сформированной на почве православия. Во второй объектом исследовательского внимания автора стали проявления мистицизма, присутствовавшие в русской литературе советской эпохи (в частности, в творчестве А. Блока, М. Горького, С. Есенина и Б. Пастернака), в своем идеологическом аспекте, как ни парадоксально, программно антирелигиозной и антимистической. В третьей, в свою очередь, он указал ключевое значение категории «пасхальности» в русской словесности на протяжении всей ее истории, будучи убежденным, что именно пасхальное ожидание «имеет существенный архетипический смысл [...] так или иначе охватывающий все пространство русской культуры - как духовной, так и светской» ${ }^{1}$.

Четвертая из этих монографий была, что подчеркивает сам И. Есаулов, его авторской формулой-предложением нового способа понимания и интерпретации русской литературной классики. В соответствии с ней русская литература рассматривается как неотъемлемая часть русской культуры, которая генетически является культурой православной. Вследствие вышеизложенного для понимания произведений наиболее значимых творцов русской литературы (не только А. Пушкина, Н. Гоголя, Ф. Достоевского или А. Чехова, но и тех, которые, как Л. Толстой или М. Салтыков-Щедрин, открыто декларировали свой разрыв с православной традицией) следует прежде всего «актуализировать» ее «православный код». Его образуют, конкретизирует Есаулов, соборность, пасхальность, христоцентризм и пасхальный архетип, противопоставленный рождественскому архетипу и в сопоставлении с ним артикулирующий противоположность Закона и Благодати, юродства и шутовства. Как показывает автор, по-прежнему присутствующие в русской культуре и литературе элементы-структуры этого «кода», претерпевшие многообразные исторические метаморфозы, особенно впечатляюще заметные в литературных произведениях рубежа

\footnotetext{
${ }^{1}$ И. А. Есаулов, Пасхальность русской словесности, Москва: Круг 2012, с. 21.
} 
XIX и XX веков, а также механизмы маскировки, наиболее интенсифицированные в литературе советского периода, по-прежнему сильны в русской литературе и культуре ${ }^{2}$.

Характеризуя общетеоретические основы производимого им в рассматриваемой книге анализа, Есаулов указывает на Диалектику мифа Алексея Лосева и написанную спустя три десятилетия Мифологию Ролана Барта, авторы которых «пытались освободиться от их [т. е. мифологических конструкций, структур и содержаний - М. Б.] господства» (c. 3). Предпринятые ими попытки, диагностирует автор, однако, принесли неприемлемые для него результаты: в случае с Бартом они привели к постструктуралистской релятивизации всех ценностей, а в случае с Лосевым закончились де-факто «утверждением абсолютного мифа», обнаруженного им в византийско-московском православии, который занял место «отвергаемых относительных мифологий». Усилия самого Есаулова, сосредоточенные в особенности на анализе постсоветских проявлений мифологии, господствующих в современной России, также имеют программно когнитивноэмансипационный характер. Предпринимая их, он пытается программно разработать и «занять некую „позицию вненаходимости” по отношению к этим структурам [т. е. к постсоветским структурам повседневности М. Б.] ради вполне „объективистического” их описания», а предпосылку возможности сделать это усматривает, в частности, в том, что он не принадлежит «ни к одному из сколько-нибудь влиятельных общественно-политических кланов» (с. 5). Вышеупомянутая убежденность сопровождается у него в то же время чувством интеллектуально-общественного одиночества: «последние организованные движения, которым я бы мог вполне сочувствовать, спешно ликвидированы в начале 20 -х годов XX века» (с. 5).

Рассматривая проблему с позиции стороннего наблюдателя, если уж он так понимает свою интеллектуальную и социальную обязанность, ему приходится просто «делать свое дело». Однако при чтении книги чувствуется, что в субъективном сознании автора ожидания-надежды идут гораздо дальше, связываясь с перспективой возможного (осуществляемого приложением подобных усилий) освободительного преображения русских и России. В предлагаемом им способе понимания мира, истины, ценностей, православия, общества, власти, политики и т.д., кроме элементов, выражающих намеренно радикальную дистанцию-разрыв в отношении к существующей форме русской действительности, можно, однако, обнаружить и целый ряд содержаний, присутствующих в главном течении русской интеллектуально-культурной традиции и общественном

${ }^{2}$ И. А. Есаулов, Русская классика: Новое понимание, [Электронный ресурс] http:// esaulov.net/wp-content/uploads/2012/07/Esaulov-Russkaja-Klassika-Novoe-Ponimanie-Vvedenie. pdf [20.09.2016]. 
сознании. К ним относятся, в частности, дихотомизирующие противопоставления Истины и анти-Истины, «здешней» и подлинной реальности, коллективизма и соборности, революции и России, советскости и русскости, РФии и России и т. д.

Лелеемая на протяжении веков многими русскими вера в возможность ожидаемого сущностного преображения - вывода России за пределы мучительно переживаемых дихотомичностей к подлинности, соборности и Истине - сопровождается в то же время, как показывает периодически повторяющийся исторический опыт, процессами самовоспроизведения ситуации, которая уже породила и в своих очередных новых-старых метаморфозах снова порождает осуществление аналогичных попыток. Более того, попытки «победного» разрыва с прошлым (предшествующим), как представляется, де-факто сопровождаются даже преобладающими в них элементами ментально-институционального системного подобия и продолжения. В качестве примера здесь можно привести архаическое восприятие России в категориях «души мира», православную идею Москвы-Третьего Рима и большевистскую концепцию Советской России (и СССР) как зародыша всего мирового коммунистического сообщества, в котором заменителем-суррогатом обожения мира становится его большевистско-коммунистическое преображение. Обнаружению разнообразных проявлений и последствий вышеизложенного в русской интеллектуально-культурной традиции и общественном сознании, выросших на почве православия, сохраняющих в то же время множество черт, свойственных архаичному восприятию мира, не способствует типичная для них тенденция к стиранию четкости различения sacrum и profanum, священного и профанного знания, истории и эсхатологии. Как признается Иван Есаулов, каждое свое исследование он рассматривает как «своего рода вызов (или ответ на вызов)» (с. 565). Таким образом, если бы я должен был предложить сферу проблематики, которая могла бы (должна бы была?) стать для него таким вызовом, я бы указал на упомянутые выше обстоятельства и вопросы.

Когда Есаулова спросили, является ли его интеллектуально-исследовательская самоидентификация филологической или философской, он ответил, на мой взгляд, точно и обоснованно: «я себя считаю филологом, но саму филологию понимаю, может быть, шире, чем принято» (с. 565). Очень высокой оценки заслуживают проявленные в книге эрудиция и содержательная компетентность автора в области великой русской литературы и ее исторических и современных исследований, аналитических разработок и интерпретаций. Об этом свидетельствуют, в частности, анализ русского и советского восприятия творчества Гоголя, С. Аксакова, дискуссия с предложенной И. Шмелевым точкой зрения на Пушкинскую речь Достоевского или с функциональными интерпретациями творчества и мысли Ф. Тютчева. Не менее ценным, интересным и плодотворным представляется данный 
в книге многоаспектный анализ генеалогии русского авангарда начала $\mathrm{XX} \mathrm{века} \mathrm{и} \mathrm{механизмов} \mathrm{«советского} \mathrm{освоения} \mathrm{русской} \mathrm{классики»,} \mathrm{де-фракто}$ ведущего к уничтожающему ее подлинный смысл идеологическому творению формы и содержания этой «классики».

Предпринятые Иваном Есауловым исследовательские усилия и результаты их реализации вызывают признание и уважение прежде всего с точки зрения их несомненных эвристических достоинств: они обращают внимание на важные, зачастую не замечаемые или маргинализируемые, отодвигаемые за рамки общественного сознания проблемы и вопросы. Они несомненно дают (могут и должны давать) пищу для размышления, побуждая читателя к углубленной рефлексии и поиску собственных объяснений и решений затрагиваемых интеллектуальных и социальных проблем, действительно важных и актуальных. Поэтому не будет случайным, если я, вер нувшись к уже ранее проводившемуся мной анализу Пушкинской речи Достоевского или связи мысли Тютчева с русской имперской традицией, почувствую себя интеллектуально обязанным сделать книгу Есаулова одной из своих самых важных исследовательских точек опоры. Более того, именно знакомство со многими представленными в ней содержаниями склоняет меня к этому возвращению и будущей дискуссии с ними, рассматривая их как интеллектуальный вызов, одновременно нелегкий, вдохновляющий и необходимый.

\section{Marian Broda}

Uniwersytet Łódzki Wydział Studiów Międzynarodowych i Politologii Katedra Studiów Europejskich 90-127 Łódź ul. Składowa 43 brodamarian@uni.lodz.pl 